\title{
REMAKING WORLDS: THE URBAN LANDSCAPE OF DOMBEY AND SON
}

\author{
N. Belgin Elbir ${ }^{1}$
}

\begin{abstract}
This article examines Charles Dickens's depiction of the changing urban landscape of London in his novel Dombey and Son (1848), as an environmentally aware response to, and a powerful critique of, the processes and impact of industrialisation, urbanisation and commercialisation. The argument is inspired by Adelene Buckland's (2013) study on the significance of the science of geology in Victorian literature that regards Dombey and Son as a novel representing the author's engagement with the scientific culture of his time. I argue that this engagement informs, the novel's portrayal of the processes of change and transformation, intended to reveal, to the novel's readers and characters alike, a historical and expanding vision of the social and natural environment that draws attention, as the plot advances, to the interconnectedness and interdependence of all life, human and non-human. The urban landscape thus becomes a means of describing and exploring characters' moral perspective that Dickens presents as an essential feature of their sense of identity, and their relationship with the physical environment as well as one another.
\end{abstract}

Key words: Charles Dickens, Dombey and Son, urbanization, industrialization, the science of geology.

In Chapter Forty-seven of Dombey and Son, the narrator, reflecting on the barrier between Mr Dombey and his wife, refers to their pride as the cause of their unhappiness. He goes on to ask, "Was Mr Dombey's master vice, that ruled him so inexorably, an unnatural characteristic? It might be worthwhile, sometimes, to inquire what Nature is, and how men work to change her, and whether, in the enforced distortions so produced, it is not natural to be unnatural" (Dickens, $1848 / 2012$, p. 755-756). He then urges his readers to

"look round upon the world of odious sights - millions of immortal creatures have no other world on earth - at the lightest mention of which humanity revolts, and dainty delicacy living in the next street, stops her ears and lisps, 'I don't believe it!' Breathe the polluted air, foul with every impurity that is poisonous to health and life; and have every sense, conferred upon our race for its delight and happiness, offended, sickened and disgusted, and made a channel by which misery and death alone can enter. Vainly attempt to think of any simple plant, or flower, or wholesome

1. Professor, Ph.D., Department of English Language and Literature, At1lim University, Ankara, Turkey, e-mail: belgin.elbir@atilim.edu.tr, ORCID: 0000-0002-2506-9819 
weed, that, set in this foetid bed, could have its natural growth, or put its little leaves forth to the sun as GOD designed it...

"Those who study the physical sciences, and bring them to bear upon the health of Man, tell us that if the noxious particles that rise from vitiated air, were palpable to the sight, we should see them lowering in a dense black cloud above such haunts, and rolling slowly on to corrupt the better portions of a town. But if the moral pestilence that rises with them, and, in the eternal laws of outraged Nature, is inseparable from them could be made discernible too, how terrible the revelation!...

"Oh for a good spirit who would take the house-tops off, with a more potent and benignant hand than the lame demon in the tale, and show a Christian people what dark shapes issue from amongst their homes, to swell the retinue of the Destroying Angel as he moves forth among them!...(Dickens, 1848/2012, p. 756-757)

Such a view would, the narrator says, rouse these people whom he addresses as "unnatural humanity" (Dickens, 1848/2012, p.757) to "a knowledge of their own relation" to the "world of human life around them"; it would show them that they are "creatures of one common origin, owning one duty to the Father of one family, and tending to one common end, to make the world a better place!" (Dickens, 1848/2012, p. 757-758).

The "potent and benignant hand" is, as Williams in his The English Novel from Dickens to Lawrence (1970/1984) remarks, the hand of Dickens, who makes the physical and moral pestilence discernible (p. 34). The passage can be regarded as an artistic manifesto, a statement of Dickens's aim and duty as an artist. It also indicates his sense of the interconnectedness of all life, human and nonhuman, and emphasizes human agency and responsibility in making the world a better place. It locates human life in its physical and natural environment within the context of the passing of time, governed by the laws of "GOD" and "the eternal laws of Nature" that rule both human life and the natural world. The setting is an urban landscape; in Dombey and Son, specifically London. The "first major creative writer in the English language to explore the full repertoire of modern urban "problems" (p. 131), as Buell, in Writing for an Endangered World (2001) describes him, Dickens creates a consciousness that discovers and recognises interconnections in the new social system. In this particular passage he expresses the great need for this kind of consciousness. The passage is also a remarkable instance of how the scientific culture of his time provided Dickens with a means of articulating imaginatively, for the purposes of his social critique, this sense of interconnectedness. For it is through the narrator's reference to physical scientists to draw attention to the effects of the "noxious particles that rise from vitiated air" on health, and the connection he establishes 
between the environmental hazards and the "moral pestilence that rises with them" that Dickens arrives at his vision of "common humanity".

My aim in this article is to examine the terms and implications of Dickens's engagement with science and new scientific ideas out of which he shapes, in the words of Williams, "a dramatic method which is uniquely capable of expressing the experience of living in cities" (1970/1984, p.32), at a time of unprecedented environmental and social change as a consequence of rapid industrialization, urbanization and commercialization. The ultimate goal of this dramatic method is to present a vision and social critique of the new conditions, that would help his readers and fictional characters reach an awareness of their common humanity. I will argue that this vision embodies Dickens's environmental consciousness and the terms of his social critique, and as such determines the form and content of the narrative. An important aspect of Dickens's depictions of both the physical and the human landscape is that they are informed by ideas and concepts derived from science, in other words the scientific culture of the nineteenthcentury, in particular, the studies and discoveries in biological science, geology, medicine, energy physics. In fact, as Parkins and Adkins (2018) assert, "the changeable relation between humans, other species, and their environments was a central insight of nineteenth-century science" (p. 5), an insight that led to a "growing sense of life as an entanglement" (p. 1). Dombey and Son is a novel that dramatizes this insight.

My argument is inspired by Adelene Buckland's discussion on the significance of Dickens's interest in geology in her Novel Science (2013) as an example of his application of contemporary scientific concepts in his novels to present his vision of the changing physical and social urban landscape. Buckland maintains that "Dickens finds in geology a form for the chaos of modernization and urbanization: like the fragmented strata it too needs reorganization" (2013, p. 261-262). This is a form that enables him to show not only the destructive process of urbanization and industrialization and its consequences, but also possibilities for the emergence of a new social order that could make the world a better place. Buckland cites the following passage from Dickens's "Review of Robert Hunt's The Poetry of Science" (1848), where, she writes, Dickens "sets out enthusiastically his ideal version of science and its relatedness to artistic and creative endeavour" (2013, p. 254):

Science has gone down into the mines and coal-pits, and before the safetylamp the Gnomes and Genii of those dark regions have disappeared... Sirens, mermaids, shining cities glittering at the bottom of quiet seas and in deep lakes, exist no longer; but in their place, Science, their destroyer, shows us whole coasts of coral reef constructed by the labours of minute creatures; points to our own chalk cliffs and limestone rocks as made of the dust of myriads of generations of infinitesimal beings that have 
passed away; reduces the very element of water into its constituent airs, and recreates it at her pleasure. Caverns in rocks, choked with treasures shut up from all but the enchanted hand, Science has blown to atoms, as she can rend and rive in the rocks themselves; but in those rocks she has found, and read aloud, the great stone book which is the history of the earth, even when darkness sat upon the face of the deep. Along their craggy sides she has traced the footprints of birds and beasts, whose shapes were never seen by man. From within them she has brought the bones, and pieced together the skeletons, of monsters that would have crushed the noted dragons of the fables at a blow. (qtd. in Buckland, 2013, p. 254-255).

As Buckland asserts, Dickens is saying that science "does not merely 'destroy' fantastical and aesthetic elements of mythology but converts them into newer understandings, replete with that older sense of wonder and awe" (2013, p. 255). The poetry of science, in other words, can stimulate the imagination, and "read the great stone book which is the history of the earth". Science can show ways of reorganizing the fragments she has discovered. This capacity of science corresponds to Dickens's goal of "making discernible", to the "unnatural humanity", the connections that exist between themselves and the world around them, so that they could work towards making the world a better place for all. As Buckland puts it, "the remaking of worlds that characterizes the narrative of Dombey and Son" is the form that Dickens finds in geology (2013, p. 267). In the novel, this "remaking" takes the form of portrayals of moments of crisis, loss and disorientation in the lives of the community and individuals, whereby their world is destroyed, and needs to be "remade". The perception of, and the response to, the urban environment are essential aspects of this experience of crisis and the act of "remaking" that follows it.

Dickens organizes his fictional world in such a way that the mentality and attitude that alienated people from their environment and one another can be demonstrated and identified as inseparable from the forces at work in the new social and physical urban landscape. At the very beginning of the novel, in the chapter about the birth of Paul and the death of Mrs Dombey at childbirth, the narrator describes Mr Dombey, the wealthy merchant and owner of "the famous House of Dombey and Son" (Dickens, 1848/2012, p. 945), as a man obsessed with one idea: "The earth was made for Dombey and Son to trade in, and the sun and moon were made to give them light. Rivers and seas were formed to float their ships; rainbows gave them promise of fair weather; winds blew for or against their enterprises, stars and planets circled in their orbits, to preserve inviolate a system of which they were the centre." (Dickens, 1848/2012, p. 2). Mr Dombey is presented as a man unable to see himself and his superior position in the world as belonging to a common humanity that is a part of a vast universe, "tending to one common end": "Common abbreviations took new meanings in his eyes, and 
had sole reference to them. A. D. had no concern with anno Domini, but stood for anno Dombei - and Son" (Dickens, 1848/2012, p. 2). Mr Dombey's pride is, as Hardy (1983) observes, "shown as capitalistic pride, the paternal pride acting in the interest of transactional possessiveness and expansion (p. 59). Thus, $\mathrm{Mr}$ Dombey's moral world and "master-vice" are related to his social position as a representative of the newly-affluent class that has become powerful through their commercial activities that were made possible by the processes of change, and that, in their turn, contributed to these processes.

Dickens extends this mentality to the way the educational system works, when little Paul is sent to school. Dr Blimber's Academy is described by the narrator as completely indifferent to children's needs:

Dr Blimber's establishment was a great hot-house, in which there was a forcing apparatus incessantly at work. All the boys blew before their time. Mental green-peas were produced at Christmas, and intellectual asparagus all the year around. Mathematical gooseberries (very sour ones too) were common at untimely seasons, and from mere sprouts of bushes, under Doctor Blimber's cultivation. Every description of Greek and Latin vegetable was got off the driest twigs of boys, under the frostiest circumstances. Nature was of no consequence. No matter what a young gentleman was intended to bear, Dr Blimber made him bear to pattern, somehow or other. (Dickens, 1848/2012, p. 168)

The artificiality of the system is contrasted with Nature, and is shown to be a "natural" outcome of the mentality represented by Mr Dombey. Blimber's Academy is, therefore, as Gilmour (1986) states, "integral to the novel's vision, providing a comic educational version of Dombeyism and its violation of "Nature"" (p. 91). There is no place in this system for imagination.

Dickens registers Dombey's character through his relation both to the natural world and to the physical environment. Dombey and Son, like other novels by Dickens, establishes connections between persons, the natural environment and physical places such as buildings, offices and rooms they inhabit. The conditions of these places are shown to indicate the characters' state of mind, and their mental and physical health. The description of the room where $\mathrm{Mr}$ Dombey, his family and guests gather on the occasion of little Paul's christening underlines this connection: The "iron-grey autumnal day, with a shrewd east wind blowing - a day in keeping with the proceedings" (Dickens, 1848/2012, p. 63), is immediately connected with Mr Dombey, who "represented in himself the wind, the shade, and autumn of the christening. He stood in his library to receive the company, as hard and cold as the weather; and when he looked out through the glass room, at the trees in the little garden, their brown and yellow leaves came fluttering down, as if he blighted them" (Dickens, 1848/2012, p. 63). The physical environment is "in keeping with the proceedings" as well: 
"Ugh! They were black, cold rooms; and seemed to be in mourning, like the inmates of the house" (Dickens, 1848/2012, p. 63). The room is cold and reflects the mood and cold nature of Mr Dombey, but it is also a physical effect, itself the consequence of his mentality. It is the chill of the house, because after his wife's funeral Mr Dombey decides to occupy only a few of the rooms and orders the rest to be shut up, "perhaps to preserve it for the son with whom his plans were associated" (Dickens, 1848/2012, p. 27). He has no plans for making his house a warm home for himself and his two children, his loving but neglected daughter Florence and little Paul. The entire scene is a striking example of what Williams regards as "the power of dramatizing a moral world in physical terms" (1970/1984, p. 40), and supports Williams's observation that "the physical world is never in Dickens unconnected with man" (1970/1984, p. 40).

"Dombeyism" is shown to be a violation of nature, and thus, inimical to a healthy and fulfilling life. The narrator comments, "the chill of Paul's christening had struck home, perhaps to some sensitive part of his nature, which could not recover itself in the cold shade of his father, but he was an unfortunate child from that day" (Dickens, 1848/2012, p. 108). Paul cannot thrive at Doctor Blimber's Academy either, and dies after he goes home at the end of his first term.

Against the "unnatural" frigidity of the Dombey mansion and Dombey temperament, Dickens presents the warmth, kindness, generosity and spontaneity of characters who are capable of responding to their environment and acknowledging their ties to common humanity. One of the major characters, Florence Dombey is one such person, and the narrator shows her hoping and striving patiently to gain her father's love. In Mr Dombey's "great dreary house" (Dickens, 1848/2012, p. 374), she is able to develop a healthy sense of identity. After she loses her little brother with whom she was very close, she lives without a family, for her father is entirely indifferent to her. In "her wilderness of a home" (Dickens, 1848/2012, p. 376), whose "blank walls looked down upon her with a vacant stare, as if they had a Gorgon-like mind to stare her youth and beauty into stone" (Dickens, 1848/2012, p. 374), Florence blooms, "like the king's fair daughter in the story" (Dickens, 1848/2012, p. 376). She believes her father does not know how much she loves him, and decides to be patient, and try to win his heart: "Always: at her books, her music, and her work: in her morning walks, and in her nightly prayers: she had her engrossing aim in view" (Dickens, 1848/2012, p. 379). Her only companions, excepting the servants, are her maid, Susan Nipper, and her dog Diogenes. Her moral integrity is established in relation to her emotional connection to the world, to other human beings, and also to other species. In the early chapters of the novel, the plot develops to introduce her to people with whom she can establish warm relations. Her first meeting with Walter Gay, who would later become her husband, occurs at a moment of crisis, when she is accidentally lost and then kidnapped in a working class district of London, where she was taken with her baby brother by his nurse 
Polly Toodle and Susan to visit Polly's family, a visit that later leads to Polly's dismissal from the Dombey household, for Mr Dombey had required Polly not to see her family while she was engaged as his son's nurse. The old woman who kidnaps Florence robs her of her expensive clothes and then, conducting her through a "labyrinth of narrow streets and lanes and alleys" (Dickens, 1848/2012, p. 87), tells her to find her friends. This particular description of the city is, as Carroll (2001) states, a common feature of Dickens's work, since "his stories most often and memorably lodge themselves within the labyrinthine and historically layered topography of London" (p. 95). For Dickens's protagonists, moreover, in Carroll's words, "London is often a dangerous and bewildering wilderness" (2001, p. 95). Florence is terrified by the "bustle in the street, and more and more bewildered by it" (Dickens, 1848/2012, p. 88). She wants to find the way to her father's offices, but all she knows of them is that "they belonged to Dombey and Son, and that that was a great power belonging to the city" (Dickens, 1848/2012, p. 88). While inquiring about the way to Dombey and Son, she meets young Walter, whose uncle Mr Sol Gills, a ships' instrument maker is known to Mr Dombey. In fact, Walter has just become employed at the firm, as a favour to his uncle. Walter is moved to "speechless admiration and commiseration" (Dickens, 1848/2012, p. 90) at the sight of helpless Florence, who asks him to take care of her. They are both very happy, and go arm in arm along the streets of London:

It was growing dark and foggy and beginning to rain too; but they cared nothing for this: being both wholly absorbed in the late adventures of Florence, which she related with the innocent good faith and confidence of her years, while Walter listened as if, far from the mud and grease of Thames street, they were rambling alone among the broad leaves and tall trees of some desert island in the tropics - as he very likely fancied, for the time, they were. (Dickens, 1848/2012, p. 91)

Walter takes Florence to his home, where she is treated very kindly by his uncle, before she is taken to her father's mansion. This coincidental meeting with Walter and Mr Gills later leads to Florence's acquaintance with Mr Gill's close friend Captain Cuttle, another character whose warm feelings and capacity for attachment contrasts sharply with Dombeyism, especially when he provides a warm and safe shelter to Florence when she runs away from her father's home later in the novel. In this sense, this "adventure" of getting lost in the streets of London is a minor crisis compared with the one that leaves her homeless, but important within the entire design of the novel since these secondary characters will have an important role in revealing the possibility of a way of life that can make the world a better place.

Before the scene of Florence getting lost, while the visiting party are making their way to Staggs's Gardens, in a suburb where Polly's home is located, 
Dickens shows the neighbourhood as it was being destroyed for the building of the railroad:

The first shock of a great earthquake had, just at that period, rent the whole neighbourhood to its centre. Traces of its course were visible on every side. Houses were knocked down; streets broken through and stopped; deep pits and trenches dug in the ground; enormous heaps of earth and clay thrown up; buildings that were undermined and shaking, propped by great beams of wood. Here, a chaos of carts, overthrown and jumbled together, lay topsy-turvy at the bottom of a steep unnatural hill; there, confused treasures of iron soaked and rusted in something that had accidentally become a pond. Everywhere were bridges that led nowhere, thoroughfares that were wholly impassable; Babel towers of chimneys, wanting half their height; temporary wooden houses and enclosures, in the most unlikely situations, carcases of ragged tenements, and fragments of unfinished walls and arches, and piles of scaffolding, and wildernesses of bricks, and giant forms of cranes, and tripods straddling above nothing. There were a hundred thousand shapes and substances of incompleteness, wildly mingled out of their places, upside down, burrowing in the earth, aspiring in the air, mouldering in the water, and unintelligible as any dream. Hot springs and fiery eruptions, the usual attendants upon earthquakes, lent their contributions of confusion to the scene. Boiling water hissed and heaved within dilapidated walls; whence, also, the glare and roar of flames came issuing forth: and mounds of ashes blocked up rights of way, and wholly changed the law and custom of the neighbourhood.

In short, the yet unfinished and unopened Railroad was in progress; and from the very core of all this dire disorder, trailed smoothly away, upon its mighty course of civilisation and improvement. (Dickens, 1848/2012, p. 75-76)

The railroad is connected with the industrialized urban landscape, and it is seen as an indication of the transforming energy of science and technology. This is the process by which, as Taylor writes in The Sky of Our Manufacture (2016), "London became the capital of the first human society to pass into industrial modernity" (p. 4). Dickens presents it as a transformation for the better, for the power of technology can, the narrator implies, manifest itself in improvement. The passage is significant in terms of the structure of the plot, in other words, the form that illustrates the need to remake the world after the destruction caused by industrialization and all the attendant changes in the social and physical landscape. The railway in this scene, "encompasses the creative destruction of the modern city, its capacity to produce new forms of technologized vision amidst scenes of spectacular ruination" (Moore, 2017, p. 36). In her discussion 
of the scene as a central image in the novel, Buckland draws attention to Dickens's use of "geological language" while the narrator "closely observes 'traces,' 'fragments,' and 'treasures' in disarray, 'wildly mingled out of their places,' like fossils scattered in a moment of geological upheaval" (2013, p. 261). She adds that "Dickens taps into the realms of popular mythology and the pleasures of the scientific spectacle familiar to his readers through periodical articles, the 'dioramic' writings of geological writers, and several interlocking forms of urban display" (2013, p. 261). His language reveals that "the railroad connects the city with geographically distant places and the temporally distant monsters that lurk beneath its soils", allowing his readers and characters to travel imaginatively, suggesting his "broader social purpose" (Buckland, 2013, p. 261) of creating a sense of common humanity.

A similar scene of destruction and construction, this time in the life of the Dombey family occurs half way through the novel, when Florence, returning home with Susan after a visit to the home of Sir Barnet Skettles who kindly invited her to stay with them after the death of little Paul, is confronted with an unexpected sight:

There was a labyrinth of scaffolding raised all round the house, from the basement to the roof. Loads of bricks and stones, and heaps of mortar, and piles of wood, blocked up half the width and length of the broad street at the side. Ladders were raised against the walls; labourers were at work upon the stages of the scaffolding, painters and decorators were busy inside; great rolls of ornamental paper were being delivered from a cart at the door; an upholsterer's waggon also stopped the way; no furniture was to be seen through the gaping and broken windows in any of the rooms; nothing but workmen, and the implements of their several trades, swarming from the kitchens to the garrets. (Dickens, 1848/2012, p. 473)

The resemblance to the earlier description of Staggs's Gardens also lies in the dream-like quality of the whole scene. When Florence enters the building, she feels "as if she were in a dream" (Dickens, 1848/2012, p. 474). This recalls the construction of the railroad that the narrator had described as being "unintelligible as any dream" to the inhabitants of the neighbourhood. In the lives of both the Staggs's Gardens community and Florence, these are unsettling events that mark moments of encounters with change and crisis, that are difficult to comprehend. The Dombey mansion is, as Florence finds out later, being remade to welcome the new Mrs Dombey. However, it turns out that, contrary to Florence's hopes and expectations, this is no happy marriage that would transform the house into a happy family home.

Whereas Mr Dombey is unable, in his frigidity and selfishness, to remake the Dombey world for the better, the Staggs's Gardens community chooses to 
welcome the change: "the neighbourhood which had hesitated to acknowledge the railroad", now "boasted of its powerful and prosperous relation" (Dickens, $1848 / 2012$, p. 259). Staggs's Gardens is no longer "unintelligible as any dream"; for the area has become a Railway world. The narrator describes the change as an improvement: "There was no such place as Staggs's Gardens. It had vanished from the earth. Where the old rotten summer-houses once had stood, palaces now reared their heads, and granite columns of gigantic girth opened a vista to the railway world beyond" (Dickens, 1848/2012, p. 259). The railroad has brought prosperity to the members of the community, expanding their vision of the world. The changes in the physical landscape are also symbolic of social and economic change: "To and from the heart of this great change, all day and night, throbbing currents rushed and returned incessantly like its life's blood. Crowds of people and mountains of goods, departing and arriving scores upon scores of times in every four-and-twenty hours, produced a fermentation in the place that was always in action" (Dickens, 1848/2012, p. 260). The improvement is manifested in the lives of the novel's characters as well, for instance when Polly's husband Mr Toodle becomes employed, as he was hoping to, as an engine driver on the train.

Mr Dombey responds differently to the broadened vision of the world brought about by the train. After Paul dies, he travels by train to Birmingham with a friend, to spend some time at Leamington, a holiday resort. The account of his journey reveals his inability to see beyond his own world, and to feel part of the wider world that the journey opens up to his view. He is portrayed as caught up within his grief for his loss; he feels offended when Mr Toodle, whose wife was Paul's nurse for a short while, recognises and approaches him to offer his condolences. Mr Dombey sees on Toodle's cap "a piece of new crape" (Dickens, $1848 / 2012$, p. 331), and realizes that he is wearing it as a sign of mourning for Paul. He is enraged: "To think of this presumptuous raker among coals and ashes going on before there, with his sign of mourning! To think that he dared to enter, even by a common show like that, into the trial and disappointment of a proud gentleman's secret heart (Dickens, 1848/2012, p. 331)! In this state of mind, he finds no comfort or relief in his journey:

Tortured by these thoughts he carried monotony with him, through the rushing landscape, and hurried headlong, not through a rich and varied country, but a wilderness of blighted plans and gnawing jealousies. The very speed at which the train was whirled along, mocked the swift course of the young life that been borne away so steadily and inexorably to its fore-doomed end. The power that forced itself upon its iron way - its own - defiant of all paths and roads, piercing through the heart of every obstacle, and dragging living creatures of all classes, ages, and degrees behind it, was a type of the triumphant monster, Death. 
Away, with a shriek, and a roar, and a rattle, from the town, burrowing among the dwellings of men and making the streets hum, flashing out into the meadows for a moment, mining in through the damp earth, booming on in darkness and heavy air, bursting out again into the sunny day so bright and wide; away, with a shriek, and a roar, and a rattle, through the fields, through the woods, through the corn, through the hay, through the chalk, through the mould, through the clay, through the rock, among objects close at hand and almost in the grasp, ever flying from the traveller, and a deceitful distance ever moving slowly with him: like as in the track of the remorseless monster, Death! (Dickens, 1848/2012, p. 331-332)

This passage presents, in the rapidly shifting scenes that collapse time in space, the vividness of the character's experience. The landscape becomes a mental, psychological landscape that is connected to the character's mood. It is made clear that Dombey's glimpses through the window of the train cannot notice the "rich and varied country"; to his gloomy mind, the speed at which the train travels, is a reminder of the passing of his son, which all his wealth and power were unable to prevent. His response to what the journey reveals is presented as a question of choice; there is "darkness and heavy air", but also "the sunny day so bright and wide" that Mr Dombey chooses not to notice.

The narrator makes it evident that the railway line had provided a new perspective on the landscape, making visible the slums which the middle and upper-class travellers in the days before the coming of the train had been able to ignore. The railway which brought cities closer together travelled through both wealthy neighbourhoods and areas of poverty. The glimpses from the window serve to connect different parts of society; travellers see humble dwellings as well as expensive mansions. Towards the end of the journey, as the train approaches Birmingham, an industrial world of darkness, poverty and misery becomes discernible:

Louder and louder yet, it shrieks and cries as it comes tearing on resistless to the goal: and now its way, still like the way of Death, is strewn with ashes thickly. Everything around is blackened. There are dark pools of water, muddy lanes, and miserable habitations far below. There are jagged walls and falling houses close at hand, and through the battered roofs and broken windows, wretched rooms are seen, where want and fever hide themselves in many wretched shapes, while smoke, and crowded gables, and distorted chimneys, and deformity of brick and mortar penning up deformity of mind and body, choke the murky distance. (Dickens, $1848 / 2012$, p. 333)

Poverty is shown as inseparable from environmental degradation. In the passage above Dickens is alluding to developments in physical and medical 
sciences, and to the studies on public health reform movements of his time. As Buell observes, "in the first half of the nineteenth century, a key catalyst was systematization of public health theory thanks to the emerging field of statistics and the "sanitarian" theory that epidemic disease was caused by dirt and bad housing" (2001, p. 131). Mr Dombey has no awareness of how the upper classes, of which he is a respectable and prominent member, are responsible for this "deformity of mind and body".

Dickens presents a view of the slums of Birmingham, a growing industrial city, but his focus is on the great metropolis, London. As Taylor notes, "London was not one coherent whole but a conglomeration of multiple municipalities, an emerging and unstable metropolis, constantly coming into and going out of being, devouring the surrounding countryside and its own shantytowns and charting a course for the rampant urbanization that continues around the globe" (2016, p. 40). In Dombey and Son, this "rampant urbanization" is illustrated through a description of the neighbourhood where one of the simple, kind and warm-hearted minor characters, Harriet Carker, lives with his brother John, who is guilty of stealing money from the firm of Dombey and Son. John is truly repentant, and forgiven by Mr Dombey's father, who was the head of the firm at the time, was allowed to continue to work there as a clerk. In order to make a home for John, Harriet has left the comfortable home of his other brother, Mr James Carker, the capable manager of the firm, who has broken all his relationship with his brother, and also with his sister. The neighbourhood belongs neither to the town nor country: "The former, like the giant in his travelling boots, has made a stride and passed it, and has set his brick-andmortar heel a long way in advance; but the intermediate space between the giant's feet, as yet, is only blighted country, and not town" (Dickens, 1848/2012, p. 553). On windy and rainy days, Harriet looks with compassion upon the people who come wandering into the metropolis. These people, "foot-sore and weary, and gazing fearfully at the huge town before them, as if foreboding that their misery there would be but as a drop of water in the sea, or as a grain of sea-sand on the shore, went shrinking on, cowering before the angry weather, and looking as if the very elements rejected them" (Dickens, 1848/2012, p. 561). Harriet observes that they never returned: "Food for hospitals, the churchyards, the prisons, the river, fever, madness, vice, and death, - they passed on to the monster, roaring in the distance, and were lost" (Dickens, 1848/2012, p. 561). This is a generalising view, but Dickens presents, towards the end of the novel, a scene where, experienced by one of the major characters and as an important part of plot development, the "roaring" city becomes a felt experience for the character and reader. Florence's flight from her home takes her into the streets of the city in the early hours of the morning, when her father hits her and unjustly accuses her of being an accomplice to his second wife who has eloped with $\mathrm{Mr}$ Carker. In that scene, Florence is exposed to the bewildering confusion of the 
city. Her response to this bewildering urban environment enacts, in a sense, the shock and the feeling of alienation created by her father's blow that puts an end to her dream of a loving relationship with him. She feels lost and frightened, and tries to think of what she can do: "Where to go? Still somewhere, anywhere! She thought of the only other time she had been lost in the wide wilderness of London - though not lost as now - and went that way. To the home of Walter's uncle" (Dickens, 1848/2012, p. 779). Her faithful dog, Diogenes, follows and catches up with her, and they go on together:

With this last adherent, Florence hurried away in the advancing morning, and the strengthening sunshine, to the city. The roar soon grew more loud, the passengers more numerous, the shops more busy, until she was carried onward in a stream of life setting that way, and flowing, indifferently, past marts and mansions, prisons, churches, market-places, wealth, poverty, good and evil, like the broad river, side by side with it, awakened from its dreams of rushes, willows, and green moss, and rolling on, turbid and troubled, among the works and cares of men, to the deep sea. (Dickens, 1848/2012, p. 780)

Dickens places this particular moment of crisis in Florence's life within the context of the "wide wilderness of London" and the life of the city, and then connects this life to the flow of the river Thames rolling on, through the streets of London, to the vast sea. These symbols of the flow of time and eternity which frame the action have the effect of enforcing a sense of the vastness and interconnectedness of all life. Throughout the novel, Dickens emphasizes that the river connects all humanity, carrying all into the vast sea that surrounds the earth and into which all human life is bound to drift. At the end of the first chapter, the dead mother drifts out upon "the dark and unknown sea that rolls round all the world" (Dickens, 1848/2012, p. 12), at Dr Blimber's Academy, little Paul continually hears the waves speaking to him and asks Florence what it is the sea keeps on saying (Dickens, 1848/2012, p. 130). Later, when he goes home and is too ill to rise from his bed, Dickens shows Paul's consciousness in interaction with his environment. It is as if he is trying to compensate for his sense of loss and loneliness. He not only hears the river speaking, which is metaphoric, but he actually responds to his surroundings, the noise in the street, the sun, the arrival of the night, and the river flowing through London (Dickens, $1848 / 2012$, p. 263). His fancy has "a strange tendency to wander to the river, which he knew was flowing through the great city; and now he thought how black it was, and how deep it would look, reflecting the hosts of stars - and more than all, how steadily it rolled away to meet the sea" (Dickens, 1848/2012, p. 263). Always a very perceptive and fanciful child, he seems to have a powerful sense of the interrelatedness of life. In the scene of Paul's death, Dickens makes use of religious language and attributes meaning to the vast, inhuman expanse of which human life is only a small part: 
The golden ripple on the wall came back again, and nothing else stirred in the room. The old, old, fashion! The fashion that came in with our first garments, and will last unchanged until our race has run its course, and the wide firmament is rolled up like a scroll. The old, old fashion Death!

Oh thank GOD, all who see it, for that older fashion yet, of immortality! And look upon us, angels of young children, with regards not quite estranged, when the swift river bears us to the ocean! (Dickens, 1848/2012, p. 268-269)

According to Picker (2002), the use of "speaking waves" in the novel demonstrates Dickens's interest in the scientific culture of his time (p. 92). The image of the sea and the waves speaking, the roaring sound of the train and the roaring streets derive from these ideas. Picker cites the passage in the novel where the narrator describes Sir Barnet Skettles, as "like a sound in the air, the vibration of which, according to the speculation of an ingenious modern philosopher, may go travelling for ever through the interminable fields of space" (Dickens, 1848/2012, p. 401 qtd. in Picker, 2002, p. 90), and writes that this philosopher was Charles Babbage, a friend of Dickens and the inventor of the Difference Engine, which was considered the first computer (Picker, 2002, p. 91). Picker identifies the passage describing Sir Barnet as referring to the ninth chapter of Babbage's The Ninth Bridgewater Treatise: A Fragment (1837), entitled "On the Permanent Impression of Our Words and Actions on the Globe We Inhabit", and adds that for Babbage, the air and the ocean waves act as a kind of giant phonograph and keep records of all vibrations that pass over them in such a way so as to bear, in the words of Babbage, "enduring testimony of the acts we have committed" (2002, p. 91). I would argue that these images are also embodiments of Dickens's desire to impart to his readers the poetry of science which could help make the world a better place, by showing them and the characters of the novel, their common humanity and common fate. The sound of the wind and rain in the passage "Let him remember it in that room, years to come. The rain that falls upon the roof, the wind that mourns outside the door, may have fore-knowledge in their melancholy sound. Let him remember it in that room" (Dickens, 1848/2012, p. 974) that occurs as a refrain in the chapter describing Mr Dombey at home after the loss of his firm and fortune, realizing gradually and with great sadness, that it is the loss of his daughter that only matters, is a striking instance that gains significance in relation to a much earlier passage. At the beginning of the novel, the narrator's description of Mr Dombey's pride was meant to show that he thought himself master of these natural elements, but it is proved that he is not; the wind and rain know more than he does. It is the knowledge of the wind and rain that bears testimony to how the natural feelings he destroyed in his young daughter's innocent heart were "snowing down on him in ashes" (Dickens, 1848/2012, p. 974). In the implications of this use of 
not only the wind and rain, but the river and the waves of the sea, Dickens can be regarded as challenging the claims of humanity's power to control nature. Thus, while affirming the significance of human agency, he also restricts it in his attempt to reconcile science with religion.

The sea, a symbol of eternity, figures at the end of the novel as well. The closing chapter presents an image of life remade for the better for Mr Dombey and Florence: "Autumn days are shining, and on the sea-beach there are often a young lady, and a white-haired gentleman. With them, or near them are two children: boy and girl. And an old dog is generally in their company" (Dickens, 1848/2012, p. 1021). It is through Florence and Walter, two people whose imaginative capacity and ability to relate to other people transformed the muddy streets of London into the pleasant image of "the tropics" during their first meeting, and their children, that Mr Dombey can finally arrive at the awareness of his need for genuine, warm relations with human beings. Dombey and Son is, indeed, a novel that demonstrates how the novelist's "potent and benignant hand" that the narrator asked for in Chapter Forty-seven can, after all, remake the world.

\section{References:}

Buckland, A. (2013). Novel Science: Fiction and the Invention of NineteenthCentury Geology. Chicago, London: The University of Chicago Press.

Buell, L. (2001). Writing for an endangered world literature, culture, and environment in the U.S. and beyond. Cambridge, MA: Belknap Press of Harvard University Press.

Carroll, J. (2001). The ecology of Victorian fiction. Philosophy and Literature, 25(2), 295-313. doi:10.1353/phl.2001.0024.

Dickens, C. (2012). Dombey and Son. London: Penguin English Library. (Original work published 1848)

Gilmour, R. (1986). The novel in the Victorian age: A Modern Introduction. London: Edward Arnold.

Hardy, B. (1983). Charles Dickens: The writer and his work. Windsor, Berkshire: Profile Books.

Moore, B. (2017) The railway and the river: Conduits of Dickens' imaginary city. In E. Murail \& S. Thornton (eds), Dickens and the Virtual City. Palgrave Studies in nineteenth-century writing and culture. Palgrave Macmillan, Cham. https://doi. org/10.1007/978-3-319-35086-8_2

Parkins, W., \& Adkins, P. (2018). Introduction: Victorian ecology and the anthropocene. 19: Interdisciplinary Studies in the Long Nineteenth Century, 26, 1-15. doi:10.16995/ ntn. 818 
Picker, J. M. (2002). The tramp of a fly's footstep: Or, the shriek, rattle and roar of a Victorian sound track. The American Scholar, 71(2), 85-94. Retrieved August 12, 2020, from http://www.jstor.org/stable/41213297

Taylor, J. O. (2016). The sky of our manufacture: The London fog in British fiction from Dickens to Woolf. Charlottesville: University of Virginia Press.

Williams, R. (1984). The English novel from Dickens to Lawrence. London: Hogarth. (Original work published 1970) 